\title{
Diagnostic Efficacy of Clinical Diagnosis, Histopathological Diagnosis as Compared to Direct Immunofluorescence in Autoimmune Blistering Diseases - A Study from South Kerala
}

\author{
Pranaya Ashwanikumar Bagde르 Beena Sunny², Rani Mathew ${ }^{3}$ \\ 1,2Department of Dermatology and Venereology, Government Medical College, Alappuzha, Kerala, India. \\ 3Department of Dermatology and Venereology, Government Medical College, Thiruvananthapuram, Kerala, India.
}

\section{ABSTRACT}

\section{BACKGROUND}

Autoimmune blistering diseases contribute to a significant number of patients attending the dermatology department. As they have a varied presentation, definite clinical diagnosis is not possible always. Histopathology is also inconclusive sometimes. Immunofluorescence studies are now considered to be most valid in diagnosing these problems. Direct immunofluorescence study of perilesional skin will help us to identify the type of immunoreactants and their exact site of location. This may help dermatologist to make accurate and prompt diagnosis. Hence we decided to conduct this study.

\section{METHODS}

We conducted a diagnostic tool evaluation cross sectional study in 34 patients, who attended dermatology outpatient department (OPD) of a major tertiary care centre in South Kerala, with a clinical diagnosis of immunobullous disease. We performed histopathology and direct immunofluorescence (DIF) in all our patients.

\section{RESULTS}

Age group of study population ranged from 31 - 90 years with a definite female preponderance. $32.4 \%$ of our patients had intraepidermal immunobullous diseases while rest had subepidermal disorders. Pemphigus vulgaris was the commonest intraepidermal disease reported, with most patients presenting in fifth and sixth decade. Oral erosions were the presenting symptom in $97.5 \%$ patients. Classical histopathology was seen in all except one, clinicopathological correlation being 87.5 $\%$. Pemphigus erythematosus could be diagnosed only by DIF. Direct immunofluorescence had $100 \%$ negative predictive value (NPV). Among subepidermal immunobullous diseases, bullous pemphigoid was seen in 19 patients with age ranging from 41 - 90 years. Clinical, histopathological and DIF correlation in bullous pemphigoid was $100 \%$. Clinical diagnosis of lichen planus pemphigoids and bullous systemic lupus erythematosus could be confirmed by histopathology and DIF while linear IgA disease showed features of bullous pemphigoid in DIF. Positive and negative predictive value reached $100 \%$ in the present study.

\section{CONCLUSIONS}

Direct immunofluorescence study is a useful investigation for the correct diagnosis of various immunobullous diseases although histopathology is more relevant in diagnosis of certain subtypes of pemphigus.

\section{KEY WORDS}

Immunobullous Diseases, Direct Immunofluorescence, Histopathology.
Corresponding Author:

Dr. Rani Mathew,

Associate Professor,

Dept. Dermatology \& Venereology,

Government Medical College,

Thiruvananthapuram, Kerala, India.

E-mail: raniguild@yahoo.co.in

DOI: $10.14260 / j e m d s / 2021 / 787$

How to Cite This Article:

Bagde PA, Sunny B, Mathew R. Diagnostic efficacy of clinical diagnosis, histopathological diagnosis as compared to direct immunofluorescence in autoimmune blistering diseases - a study from South Kerala. J Evolution Med Dent Sci 2021;10(45):3895-3899, DOI: 10.14260/jemds/2021/787

Submission 13-11-2021,

Peer Review 19-11-2021,

Acceptance 13-12-2021,

Published 28-12-2021.

Copyright @ 2021 Pranaya Ashwanikumar Bagde et al. This is an open access article distributed under Creative Commons Attribution License [Attribution 4.0 International (CC BY 4.0)] 


\section{BACKGROUND}

Autoimmune vesiculobullous disorders (Immunobullous disorders) are a group of diseases where antibody mediated autoimmune response occurs against various adhesion molecules of epidermis and basement membrane zone. ${ }^{1}$ Significant improvement has been made in our knowledge about these adhesion molecules of skin which led to proper classification, diagnosis and understanding of the immunopathologic basis of these immunobullous diseases. ${ }^{2}$ Based on location of blister cleavage, these disorders are divided into two groups - intraepidermal and subepidermal immunobullous diseases. ${ }^{1}$ Intraepidermal blistering diseases include pemphigus vulgaris and its variant pemphigus vegetans, pemphigus foliaceus and its variant pemphigus erythematosus, pemphigus herpetiformis, IgA pemphigus, drug induced pemphigus and paraneoplastic pemphigus. Subepidermal immunobullous diseases are bullous pemphigoid, mucous membrane pemphigoid, pemphigoid gestationis, linear IgA disease (LAD), epidermolysis bullosa acquisita (EBA), cicatricial pemphigoid, bullous systemic lupus erythematosus, LP pemphigoides, anti p200 pemphigoid and dermatitis herpetiformis. ${ }^{1}$

Immunofluorescence technique, used to detect immunoreactants like immunoglobulins (IgG, IgM IgA and IgE) complement and fibrin in patient's tissue, is a gold standard tool to confirm the diagnosis suspected by clinical and histopathological examination. ${ }^{2}$ Direct immunofluorescence (DIF) technique uses frozen section of patients skin on which fluorescein isothiocyanate or rhodamine isothiocyanate conjugated antibody to immunoglobulins and complement is added. Positive reaction is indicated by apple green or red fluorescence respectively at sites of immunoprotein deposits which is recognized under fluorescent microscope. We can assess the degree of fluorescence, but antibody titre cannot be estimated by DIF. Antibodies in serum, and blister fluid can be demonstrated by indirect immunofluorescence (IIF) technique. Here monkey esophagus, rat bladder or human skin is used as the substrate and it is a two-step procedure. Antibody titre can be detected and it directly correlates with the disease activity.1,2

Histopathological findings along with clinical correlation form the basis of diagnosis in many cases. But in some cases overlap of clinical and histopathological features make a definite diagnosis difficult. Direct immunofluorescence helps to identify the immunoreactants, their pattern and exact site of deposits which aids in better diagnosis and ensure proper treatment at the earliest.

\section{Aims \& Objectives}

Our aim was to study the diagnostic efficacy of clinical and histopathological diagnosis as compared to direct immunofluorescence findings in immunobullous diseases.

\section{METHODS}

We did a cross sectional diagnostic tool evaluation study. A total of 34 patients with clinical diagnosis of autoimmune immunobullous diseases who attended dermatology and venereology department of a major tertiary care centre in South Kerala during the study period of 2 years from January 2010 were included. Patients on specific therapy and those not willing for study were excluded from the present study.

After detailed history, dermatological examination, systemic assessment and a Tzanck smear, a provisional clinical diagnosis was made. Incisional lesional skin biopsy was taken, put in formalin and sent for histopathology examination (H \& E stain). A $5 \mathrm{~mm}$ punch biopsy from perilesional skin was obtained for direct immunofluorescence study, washed in saline and transported to lab in Michel's medium. In lab it was washed with phosphate buffered saline followed by tissue freezing. Sections were taken and treated with fluorescein isothiocyanate labelled antisera and incubated. These sections were mounted on buffered glycerol and examined under fluorescence microscope. Type of immunoreactants, site of deposition and pattern were noted.

\section{Statistical Analysis}

All the data was entered in Microsoft Excel spread sheet and analyzed using Statistical Package for Social Sciences (SPSS) software. The clinical, pathological and direct immunofluorescence findings were recorded and analyzed in terms of frequency and percentage of co-relationship. The significance of association between clinical, histopathological and DIF findings were assessed with the help of appropriate biostatistics.

Permission to conduct study was obtained from Institutional Ethics Committee before starting the project. Prior written informed consent was obtained from all the participants.

\section{RESULTS}

The age group of study population ranged from 31- 90 years with maximum patients being in $41-50$ year age group. $\mathrm{M}: \mathrm{F}$ ratio was $0.96: 1$ in our patients.

Out of 34 patients, 11 (32.4\%) had intraepidermal diseases while rest $23(67.6 \%)$ had subepidermal diseases.

\section{Intraepidermal Group}

In this group, the age varied from 31 - 70 years with maximum patients in fifth and sixth decade. Ten of them were females. 
patients. Histopathology showed supra basal blister with acantholytic cells and tombstoning of basal layer in seven cases while one showed subepidermal bulla with basal cell necrosis. Our study showed $87.5 \%$ clinicopathological correlation. In pemphigus vulgaris patients, histopathology and DIF showed consistent findings in all except one where histopathology was suggestive of erythema multiforme and DIF negative. DIF had $100 \%$ negative predictive value in this case.

Moist, crusted, and scaly erosions were observed in pemphigus foliaceus patients with involvement of nose and malar areas in the erythematosus variant. A sub corneal blister with acantholysis was seen in both. Diagnosis of pemphigus erythematosus could be confirmed only by DIF. Other case showed intercellular deposits of IgG and C3 throughout epidermis suggestive of pemphigus only.

The histopathology and DIF in clinically diagnosed paraneoplastic pemphigus was suggestive of pemphigus vulgaris.

Clinical, histopathological and DIF correlation of intraepidermal immunobullous diseases is shown in Table 1.

\begin{tabular}{|c|c|c|c|c|}
\hline $\begin{array}{l}\text { No. of } \\
\text { Cases }\end{array}$ & $\begin{array}{l}\text { Clinical } \\
\text { Diagnosis }\end{array}$ & $\begin{array}{c}\text { Histopathological } \\
\text { Diagnosis }\end{array}$ & $\begin{array}{c}\text { DIF } \\
\text { Diagnosis }\end{array}$ & $\begin{array}{c}\text { Final } \\
\text { Diagnosis }\end{array}$ \\
\hline 7 & $\begin{array}{l}\text { Pemphigus } \\
\text { vulgaris }\end{array}$ & $\begin{array}{l}\text { Pemphigus } \\
\text { vulgaris }\end{array}$ & $\begin{array}{l}\text { Pemphigus } \\
\text { vulgaris }\end{array}$ & $\begin{array}{l}\text { Pemphigus } \\
\text { vulgaris }\end{array}$ \\
\hline 1 & $\begin{array}{l}\text { Pemphigus } \\
\text { vulgaris }\end{array}$ & $\begin{array}{l}\text { Erythema } \\
\text { multiforme }\end{array}$ & Negative & $\begin{array}{l}\text { Erythema } \\
\text { multiforme }\end{array}$ \\
\hline 1 & $\begin{array}{c}\text { Pemphigus } \\
\text { foliaceus } \\
\text { (erythematosus } \\
\text { variant) }\end{array}$ & $\begin{array}{l}\text { Pemphigus } \\
\text { foliaceus }\end{array}$ & $\begin{array}{c}\text { Pemphigus } \\
\text { foliaceus } \\
\text { (erythematosus } \\
\text { variant) }\end{array}$ & $\begin{array}{c}\text { Pemphigus } \\
\text { foliaceus } \\
\text { (erythematosus } \\
\text { variant) }\end{array}$ \\
\hline 1 & $\begin{array}{l}\text { Pemphigus } \\
\text { foliaceus }\end{array}$ & $\begin{array}{l}\text { Pemphigus } \\
\text { foliaceus }\end{array}$ & Pemphigus & $\begin{array}{l}\text { Pemphigus } \\
\text { foliaceus }\end{array}$ \\
\hline 1 & $\begin{array}{l}\text { Paraneoplastic } \\
\text { pemphigus }\end{array}$ & $\begin{array}{l}\text { Pemphigus } \\
\text { vulgaris }\end{array}$ & $\begin{array}{l}\text { Pemphigus } \\
\text { vulgaris }\end{array}$ & $\begin{array}{l}\text { Pemphigus } \\
\text { vulgaris }\end{array}$ \\
\hline \multicolumn{5}{|c|}{$\begin{array}{l}\text { Table 1. Clinical, histopathological and DIF Correlation in } \\
\text { Intraepidermal Immunobullous Diseases }\end{array}$} \\
\hline
\end{tabular}

Sensitivity and specificity of direct immunofluorescence compared to clinical and histopathological diagnosis of intraepidermal blistering diseases is shown in Table 2 and 3 respectively.

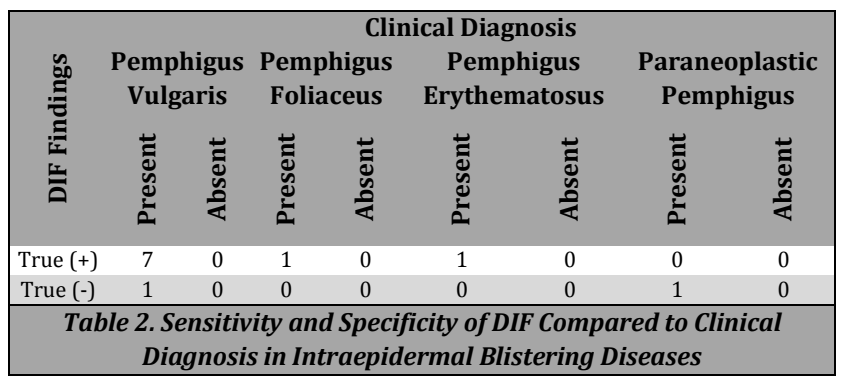

\begin{tabular}{|c|c|c|c|c|c|c|}
\hline \multirow{3}{*}{ DIF Findings } & \multicolumn{6}{|c|}{ Histopathological Diagnosis } \\
\hline & \multicolumn{2}{|c|}{$\begin{array}{c}\text { Pemphigus } \\
\text { Vulgaris }\end{array}$} & \multicolumn{2}{|c|}{$\begin{array}{c}\text { Pemphigus } \\
\text { Foliaceus }\end{array}$} & \multicolumn{2}{|c|}{$\begin{array}{l}\text { Erythema } \\
\text { Multiforme }\end{array}$} \\
\hline & Present & Absent & Present & Absent & Present & Absent \\
\hline True $(+)$ & 7 & 0 & 2 & 0 & 0 & 0 \\
\hline True (-) & 0 & 0 & 0 & 0 & 1 & 0 \\
\hline
\end{tabular}

\section{Subepidermal Group}

Age varied from 41 - 90 years. There were 21 females and 2 males in the study group.
Different Clinical Diagnosis of Subepidermal Immunobullous Diseases $(n=23)$

- Bullous pemphigoid(BP)

- Linear IgA disease

- Lichen planus pemphigoides

- Bullous systemic lupus erythematosus

- Bullous erythema multiforme/Bullous pemphigoid 1

Commonest subepidermal immunobullous disease observed in this study was bullous pemphigoid, most commonly in 51 - 70 year age group. Tense blisters and urticated plaques were seen in all patients. Out of 19 patients, $4(21.05 \%)$ had oral erosions. Genital erosions were noted in only one patient ( $5.2 \%$ ). All of them showed subepidermal blisters with predominant eosinophilic infiltrate on histopathology and linear basement membrane band of predominant C3 followed by IgG on direct immunofluorescence. Clinical, pathological and DIF correlation was $100 \%$ in bullous pemphigoid in our study.

Linear IgA disease was diagnosed clinically as patient had tense blisters with string of pearls appearance and severe oral erosions. Histopathology showed subepidermal blister with neutrophils but DIF was suggestive of bullous pemphigoid. Here though a clinicopathological correlation was present, we made a final diagnosis of bullous pemphigoid as IgA was absent in DIF.

Generalized lichen planus lesions followed by appearance of vesicles and bullae over lesional and normal looking skin made us to diagnose lichen planus pemphigoids, clinically, in one case. Histopathology showed subepidermal split with features of lichen planus. DIF was suggestive of bullous pemphigoid. Clinicopathological and DIF correlation helped us to arrive at the final diagnosis.

We obtained histopathological and DIF correlation in the patient who was clinically diagnosed as bullous systemic lupus erythematosus.

One patient presented to us with oral erosions, tense blisters, and target lesions and herpes iris of bateman lesions. Histopathology showed features of erythema multiforme but DIF showed linear basement membrane zone deposits of C3 and IgG with absent fibrinogen.

Clinical, histopathological and DIF correlation and final diagnosis of 23 patients with subepidermal immunobullous diseases is shown in Table 4.

\begin{tabular}{|c|c|c|c|c|}
\hline $\begin{array}{l}\text { No. of } \\
\text { Cases }\end{array}$ & $\begin{array}{c}\text { Clinical } \\
\text { Diagnosis }\end{array}$ & $\begin{array}{l}\text { Histopathologic } \\
\text { al Diagnosis }\end{array}$ & $\begin{array}{c}\text { DIF } \\
\text { Diagnosis }\end{array}$ & $\begin{array}{c}\text { Final } \\
\text { Diagnosis }\end{array}$ \\
\hline 19 & $\begin{array}{l}\text { Bullous } \\
\text { pemphigoid }\end{array}$ & Bullous pemphigoid & $\begin{array}{l}\text { Bullous } \\
\text { pemphigoid }\end{array}$ & $\begin{array}{c}\text { Bullous } \\
\text { pemphigoid }\end{array}$ \\
\hline 1 & $\begin{array}{l}\text { Linear IgA } \\
\text { dermatosis }\end{array}$ & $\begin{array}{c}\text { Linear IgA } \\
\text { dermatosis }\end{array}$ & $\begin{array}{c}\text { Bullous } \\
\text { pemphigoid }\end{array}$ & $\begin{array}{c}\text { Bullous } \\
\text { pemphigoid }\end{array}$ \\
\hline 1 & $\begin{array}{l}\text { Lichen planus } \\
\text { pemphigoides }\end{array}$ & $\begin{array}{l}\text { Lichen planus } \\
\text { pemphigoides }\end{array}$ & $\begin{array}{c}\text { Bullous } \\
\text { pemphigoid }\end{array}$ & $\begin{array}{l}\text { Lichen planus } \\
\text { pemphigoides }\end{array}$ \\
\hline 1 & $\begin{array}{l}\text { Bullous systemic } \\
\text { lupus } \\
\text { erythematosus }\end{array}$ & $\begin{array}{l}\text { Bullous systemic } \\
\text { lupus erythematosus }\end{array}$ & $\begin{array}{l}\text { Bullous systemic } \\
\text { lupus } \\
\text { erythematosus }\end{array}$ & $\begin{array}{c}\text { Bullous systemic } \\
\text { lupus } \\
\text { erythematosus }\end{array}$ \\
\hline 1 & $\begin{array}{l}\text { ?Bullous } \\
\text { erythema } \\
\text { multiforme } \\
\text { ? Bullous } \\
\text { pemphigoid }\end{array}$ & $\begin{array}{l}\text { Bullous erythema } \\
\text { multiforme }\end{array}$ & $\begin{array}{c}\text { Bullous } \\
\text { pemphigoid }\end{array}$ & $\begin{array}{c}\text { Bullous } \\
\text { pemphigoid }\end{array}$ \\
\hline & Suber & ormal Immun & $\begin{array}{l}\text { and DIF Correl } \\
\text { lous Diseases }\end{array}$ & . \\
\hline
\end{tabular}


Sensitivity and specificity of DIF compared to clinical and histopathological diagnosis of subepidermal blistering diseases in shown in Table 5 and 6 respectively.
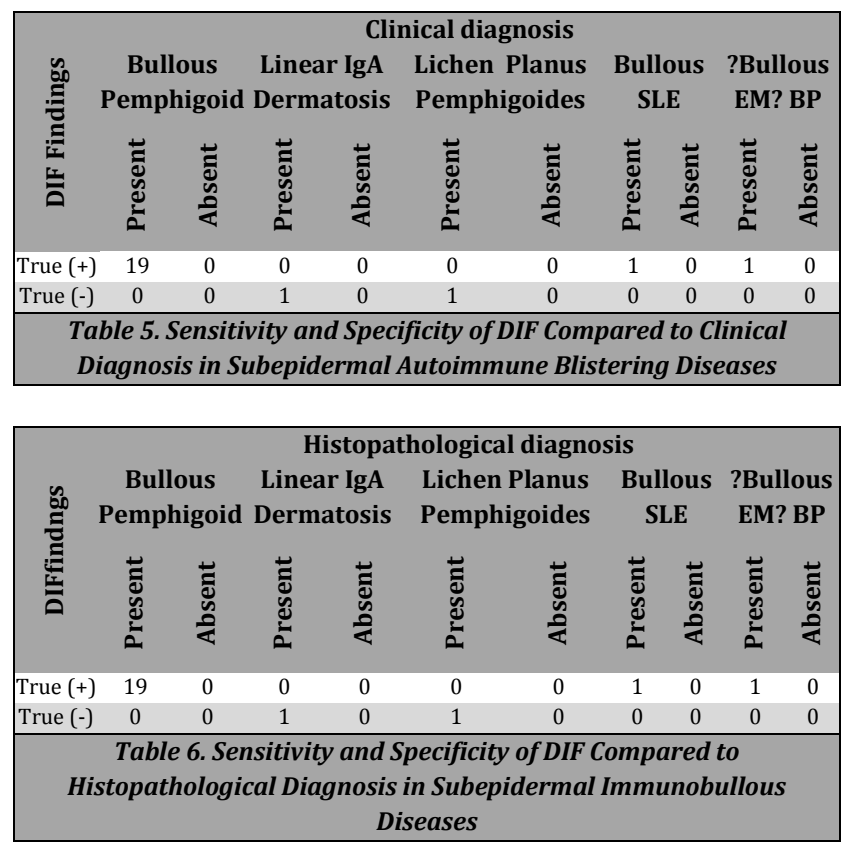

\section{DISCUSSION}

Immunobullous disorders are a heterogeneous group of dermatological disorders where histopathology and immunofluorescence supplements clinical findings to arrive at a diagnosis. DIF is a rapid and reliable diagnostic tool which permits early diagnosis and treatment of these potentially life threatening disorders. Present study was conducted to assess the diagnostic efficacy of DIF as compared to clinicopathological diagnosis in autoimmune blistering diseases.

\section{Intraepidermal Immunobullous Diseases}

We observed maximum patients in 41 - 50 year age group with a significant female preponderance. According to literature, pemphigus is a disease of middle age with a slight female predominance in some studies. ${ }^{1,3}$ Chowdhury et al. in their study from eastern India observed M : F ratio as 14 : 273. Pemphigus vulgaris was the commonest type in our area which is in accordance with studies conducted by Fernandez et al. ${ }^{4}$ Clinicohistopathological correlation in our study was $87.5 \%$. Arya et al. in their study showed $95 \%$ correlation. $^{5}$ We observed the positive predictive value (PPV) in confirming pemphigus vulgaris to be $100 \%$ which is comparable to that by Minz et al. ${ }^{6}$ The patient where histopathology came as erythema multiforme had negative DIF. DIF had $100 \%$ negative predictive value in this case.

Pemphigus erythematosus could be confirmed only by DIF. Histology and DIF findings were consistent with pemphigus vulgaris in a patient diagnosed clinically as paraneoplastic pemphigus.
One case of pemphigus foliaceus diagnosed clinically and histopathologically showed intercellular deposits of IgG throughout epidermis. Though DIF is the gold standard to diagnose pemphigus, histopathology may be more useful to determine the exact subtypes in some cases. However Black et al. observed preferential localization of immunoreactants to the upper epidermis in pemphigus foliaceus patients. ${ }^{7}$

In our study, positive and negative predictive value of DIF in confirming intraepidermal immunobullous diseases was $100 \%$. Study by Mutasim et al. found a positive predictive value of $100 \%$ by DIF in pemphigus group of disorders and a negative predictive value of $85-90 \%{ }^{2}$

Subepidermal immunobullous disorders

Maximum number of patients with bullous pemphigoid belonged to 51-70 year age group which is in concordance with available literature. ${ }^{1}$ All 19 patients who were clinically diagnosed to have bullous pemphigoid had supportive findings on histopathology and DIF. According to Mutasim et al. deposition of C3 with significantly higher intensity than IgG favours bullous pemphigoid. ${ }^{2}$ This is also evident in our study. If intensity of IgG is more, epidermolysis bullosa acquisita is the more likely diagnosis. ${ }^{2}$

One patient who had clinicohistopathological features of linear IgA disease showed linear basement membrane zone deposits of C3 and IgG, a finding consistent with bullous pemphigoid. One of our patients had clinical features of BP and erythema multiforme (EM), histology showed EM, but DIF results were typical of BP. Minz et al. in their study diagnosed bullous pemphigoid on the basis of DIF in 2 cases even though there was a clinical dilemma and no histopathological proof of BP. ${ }^{6}$

Clinical diagnosis of lichen planus pemphigoides in our case is in accordance to that described in literature. ${ }^{1}$ Kaposi et al. in their study described the histology of the same which was observed in our study also. ${ }^{8}$ DIF findings were suggestive of bullous pemphigoid.

Positive and negative predictive value of DIF in our cases of subepidermal immunobullous diseases approached $100 \%$. According to Mutasin et al. positive and negative predictive value of DIF in subepidermal diseases approaches $100 \%{ }^{2}$ False negative results may occur due to poor sampling or technical error. ${ }^{2}$ Sensitivity of direct immunofluorescence range from $82-96 \%$ in subepidermal diseases according to Seline et al. but it does not differentiate diseases like epidermolysis bullosa acquisita. ${ }^{9}$

\section{CONCLUSIONS}

Direct immunofluorescence study is the gold standard for diagnosis of immunobullous diseases. In pemphigus, histopathology is more useful to distinguish certain subtypes. Further studies with larger sample size will help to confirm our findings.

Data sharing statement provided by the authors is available with the full text of this article at jemds.com.

Financial or other competing interests: None.

Disclosure forms provided by the authors are available with the full text of this article at jemds.com. 


\section{REFERENCES}

[1] Schmidt E, Groves R. Immunobullous diseases. In: Griffiths CEM, ed. Rook's textbook of dermatology. 9th edn. UK: Wiley Blackwell 2016:1395-403.

[2] Mutasim DF, Adams BB. Immunofluorescence in dermatology. J Am Acad Dermatol 2001;45(6):803-22.

[3] Chowdhury J, Datta PK, Chowdhury SN, et al. A clinicopathological study of pemphigus in Eastern India with special reference to direct immunofluorescence. Indian J Dermatol 2016;61(3):288-94.

[4] Fernandez JC, Dharani JB, Desai SC. A study of 100 cases of pemphigus-clinical features. Indian J Dermatol Venereol Leprol 1970;36(1):1-11.

[5] Arya SR, Valand AG, Krishna K. A clinicopathological study of 70 cases of pemphigus. Indian J Dermatol Venereol Leprol 1999;65(4):168-71.
[6] Minz RW, Chhabra S, Singh S, et al. Direct immunofluorescence of skin biopsy: perspective of an immunopathologist. Indian J Dermatol Venereol Leprol 2010;76(2):150-7.

[7] Black MM, Bhogal BS, Willsteed E. Immunopathological technique in diagnosis of bullous disorders. Acta Derm Venereol 1989;151:96-105.

[8] Kaposi M. Lichen ruberpemphigoids. Arch Dermatol 1892;24:343-6.

[9] Ali ES, Lauren NS, Olayemi S, et al. Comparison of histopathology, immunofluorescence, and serology for the diagnosis of autoimmune bullous disorders: an update. Glob Dermatol 2016:3. DOI: 10.15761/GOD.1000S1005. 